\title{
PENGARUH DIMENSI KUALITAS PELAYANAN TERHADAP KEPUASAN MASYARAKAT PELAPOR PADA POLSEK TENGARAN POLRES SEMARANG
}

\author{
Oleh \\ Herlis Sukma ${ }^{1)}$, Hardi Utomo ${ }^{2)}$ \\ Sekolah Tinggi Ilmu Ekonomi AMA Salatiga
}

\begin{abstract}
Abstrak
Pelayanan yang efektif dan efisien merupakan salah satu usaha yang wajib dipenuhi oleh setiap lembaga pemerintahan termasuk lembaga kepolisian. Sebab pelayanan yang memuaskan akan membuat hubungan harmonis antara pihak masyarakat dengan lembaga kepolisian.Tujuan penelitian ini adalah : Untuk mengetahui pengaruh faktor bukti langsung (tangibles), kehandalan (reliability), daya tanggap (responsibility), jaminan (assurance) dan empati (empathy) secara simultan terhadap kepuasan masyarakat pelapor pada Polsek Tengaran Polres Semarang. Tipe penelitian dalam penelitian ini adalah eksplanatori. Data primer diperoleh dengan cara membagikan kuesioner kepada responden, sedang data sekunder diperoleh dari catatan administrasi Polsek Tengaran serta buku-buku yang menunjang. Populasi dan sampel dalam penelitian ini, yaitu seluruh masyarakat Tengaran yang melakukan pengaduan terkait dengan masalah keamanan dan ketertiban berjumlah 65 orang. Untuk itu teknik pengambilan sampel yang digunakan adalah sampling jenuh/sensus. Alat analisis data yang digunakan adalah regresi linier berganda. Hasil penelitian menunjukkan terdapat pengaruh yang signifikan variabel tangibles, reliability, responsiveness, assurance, dan empathy baik secara parsial maupun simultan terhadap kepuasan masyarakat pelapor pada Polsek Tengaran Polres Semarang. Saran dalam penelitian ini adalah manajemen Polsek Tengaran perlu mengajukan anggaran kepada pihak Polri untuk meningkatkan kualitas bangunan yang digunakan, serta meningkatkan kualitas peralatan yang digunakan, misal: peralatan komputer, baik dari aspek kualitas maupun kuantitasnya, sebab hal tersebut akan membantu mempercepat proses pelayanan yang dilakukan kepada masyarakat.
\end{abstract}

\section{Kata Kunci : Kualitas Pelayanan, Kepuasan Masyarakat}

\section{PENDAHULUAN}

Kepolisian Republik Indonesia merupakan salah satu bentuk organisasi pemerintah yang dibentuk untuk menjaga keamanan dan ketertiban dalam masyarakat. Sebagai lembaga atau organisasi yang bertugas menjaga keamanan dan ketertiban di dalam masyarakat tentu pihak kepolisian perlu memberikan pelayanan kepada masyarakat secara profesional, jujur, adil, merata dalam penyelenggaraan tugasnya, dan bersikap netral dari pengaruh semua golongan dan partai politik serta tidak diskriminatif 
dalam memberikan pelayanan kepada masyarakat. Sebab dengan sikap-sikap tersebut yang dikedepankan dalam memberikan pelayanan kepada masyarakat, akan menciptakan komunikasi yang baik antara pihak kepolisan dengan masyarakat, sehingga pelayanan yang efektif dan efisien kepada masyarakat dapat tercapai yang selanjutnya akan memupuk kepuasan masyarakat (Sasmita, 2007 : 15).

Dalam mengevaluasi apakah pelayanan yang diberikan kepada masyarakat oleh Polsek Tengaran Polres Semarang telah memenuhi harapan atau belum, umumnya masyarakat menggunakan beberapa atribut atau faktor sebagai tolak ukur (Zeithaml, Parasuraman, dan Berry dalam Lupiyoadi, 2009:148) yang dikenal dengan istilah Service Quality (SERVQUAL). Adapun dalam konsep tersebut atribut-atrbut atau faktor-faktor yang dinilai meliputi : bukti langsung (tangibles), diantaranya meliputi fasilitas fisik, perlengkapan, petugas, dan sarana komunikasi, kehandalan (reliability) meliputi : kemampuan petugas memberikan pelayanan yang dijanjikan dengan segera, akurat, dan memuaskan, daya tanggap (responsiveness) meliputi: keinginan para petugas untuk membantu pihak pelapor dan memberikan pelayanan dengan tanggap, jaminan (assurance) meliputi : kemampuan, kesopanan, dan sifat dapat dipercaya yang dimiliki para petugas; bebas dari risiko atau keragu-raguan, empati (empathy) meliputi : kemudahan dalam melakukan hubungan, komunikasi yang baik, perhatian pribadi, dan memahami kebutuhan masyarakat pelapor saat melakukan pengaduan tindak kriminalitas. Sekumpulan atribut-atribut pelayanan tersebut secara lengkap dapat digunakan sebagai kriteria dalam menilai kualitas pelayanan yang diberikan petugas Polsek Tengaran dalam memberikan pelayanan pengaduan oleh masyarakat.

Berkaitan dengan kehandalan (reliability), sebagian masyarakat menyatakan bahwa pelayanan yang diberikan oleh petugas kurang akurat, dan tidak sesuai dengan apa yang dijanjikan, contoh: kasus yang ditangani tidak segera kunjung selesai, kondisi tersebut menjadikan pelapor terpaksa harus turun tangan sendiri mengurusnya. Berkaitan dengan daya tanggap (responsiveness), pada dasarnya saat melakukan peloporan petugas cepat melakukan respond an langsung memberikan pelayanan, namun saat implementasi di lapangan terkadang kasus tidak terselesaikan dengan baik atau sesuai harapan pelapor. 
Berkaitan dengan jaminan (assurance), masalah pengetahuan anggota dinilai kurang, menurut sebagian masyarakat pelapor terdapat anggota yang kurang mampu dalam memberikan masukan secara baik dan benar terhadap permasalahan yang dihadapi oleh masyarakat. Sementara berkaitan dengan masalah empati (empathy), masyarakat pelapor menilai terdapat petugas yang kurang komunikatif dengan pihak masyarakat pelapor saat menangani kasus. Hal tersebut menjadikan masyarakat pelapor tidak mengetahui sejauhmana perkembangan kasus yang ditangani anggota.

Berdasarkan paparan latar belakang tersebut di atas, maka penting untuk menindaklanjuti sejauhmana kebenaran fakta-fakta yang diungkapkan oleh sebagian masyarakat pelapor dengan kondisi riil di lapangan. Untuk mempermudah pemahaman terhadap materi yang akan di bahas dalam skripsi ini, maka perlu adanya perumusan masalah secara sistematis. Adapun masalah yang akan dibahas dalam skripsi ini adalah : Apakah ada pengaruh dimensi kualitas pelayanan terhadap kepuasan masyarakat pelapor pada Polsek Tengaran Polres Semarang?

\section{LANDASAN TEORI DAN PENGEMBANGAN HIPOTESIS}

\section{Pemasaran}

Pemasaran berarti menggarap untuk menghasilkan pertukaran demi memuaskan kebutuhan dan keinginan manusia. Menurut Kotler (2002:12) pemasaran adalah proses sosial dan manajerial yang mengakibatkan individu dan kelompok memperoleh apa yang mereka butuhkan dan inginkan lewat penciptaan dan pertukaran produk dan nilai dari pihak lain. Menurut Asosiasi Pemasaran Amerika dalam Kotler (2002:9) pemasaran adalah proses prencanaan dan pelaksanaan pemikiran, penetapan harga, promosi, serta penyaluran gagasan, barang, dan jasa untuk menciptakan pertukaran yang memenuhi sasaran-sasaran individu dan organisasi. Jasa adalah setiap tindakan atau kinerja yang ditawarkan oleh satu pihak ke pihak lain yang secara prinsip tidak berwujud dan tidak menyebabkan perpindahan kepemilikan. Produksi jasa dapat terikat atau tidak terikat pada suatu produk fisik (Kotler, 2009:27).

\section{Kualitas Pelayanan}

Menurut Tjiptono (2004:238), kualitas pelayanan adalah suatu sikap atau cara karyawan dalam melayani konsumen secara memuaskan. Suatu cara perusahaan untuk 
tetap dapat unggul bersaing adalah memberikan pelayanan dengan kualitas yang lebih tinggi dari pesaingnya secara konsisten. Harapan konsumen dibentuk oleh pengalaman masa lalunya, pembicaraan dari mulut ke mulut yang dilakukan oleh perusahaan jasa, kemudian dibandingkannya. Sementara menurut Blomer dkk (2002:108), kualitas pelayanan merupakan perbandingan antara pelayanan sebagaimana yang diharapkan dengan persepsi kinerja aktual.

Namun dari sekian banyak konsep mengenai dimensi kualitas pelayanan, peneliti akan menggunakan ukuran dimensi kualitas pelayanan yang dikemukan oleh Tjiptono (2004:238), yaitu:

\section{Bukti langsung (tangibles)}

Bukti langsung (tangibles) adalah penampilan fasilitas fisik, peralatan, dan berbagai sarana komunikasi. Berdasarkan penjelasan tersebut maka tangibles dapat dinilai dari beberapa aspek, seperti: fasilitas fisik memadai, dukungan peralatan moderen, kerapihan dan kebersihan karyawan, sarana komunikasi.

2. Kehandalan (reliability)

Kehandalan (reliability) adalah kemampuan petugas untuk menepati janji, memberikan perhatian dalam penyelesaian masalah, mampu melakukan pelayanan dengan benar tanpa melakukan kesalahan. Berdasarkan pendapat tersebut maka aspek reliability dapat dinilai dari beberapa aspek, seperti: menepati janji, perhatian dalam penyelesaian masalah, pelayanan yang benar, tidak melakukan kesalahan.

3. Daya tanggap (responsiveness)

Daya tanggap (responsivenss) adalah kemauan petugas untuk memberikan pelayanan dan membantu dengan segera. Komponen ini dapat dinilai dari beberapa aspek, yakni: layanan mudah dimengerti, layanan secara tepat, cepat dan tanggap, bersedia membantu pelanggan, kepekaan pada permasalahan pelanggan.

4. Jaminan (assurance)

Jaminan (assurance) adalah kemampuan karyawan untuk menimbulkan keyakinan dan kepercayaan terhadap janji yang telah dikemukakan. Komponen assurance dikembangkan dari teori Tjiptono (2004:239) meliputi : tanggung jawab dan 
kepercayaan pelanggan, keamanan dan jaminan dalam transaksi, kesopanan, keramahan, penguasaan jasa yang ditawarkan.

\section{Empati (empathy)}

Empati (empathy) adalah kesediaan karyawan dan pengusaha untuk lebih peduli memberikan perhatian secara pribadi kepada langganan. Komponen empati yang dikembangkan Tjiptono (2004:240) meliputi sebagai berikut: perhatian secara pribadi, pelayanan yang nyaman, perhatian kepentingan pelanggan dan pemahaman kebutuhan khusus para pelanggan.

\section{Kepuasan Masyarakat}

Berpijak dari pendapat Tjiptono (2007:357) di atas, maka indikator yang digunakan dalam mengukur kepuasan masyarakat pelapor adalah sebagai berikut:

1. Reputasi perusahaan semakin positif di mata konsumen pada umumnya dan pelanggan pada khususnya.

2. Dapat mendorong terciptanya loyalitas pelanggan.

3. Memungkinkan terciptanya rekomendasi dari mulut ke mulut (word of mouth) yang menguntungkan bagi perusahaan sehinggga semakin banyak orang yang akan membeli dan menggunakan produk/ jasa perusahaan.

4. Hubungan antara perusahaan dan para pelanggan menjadi harmonis.

\section{Kerangka Pemikiran}

Dalam mengukur keualitas pelayanan yang diberikan oleh pihak lembaga kepolisian dapat dilakukan dengan menilai dimensi-dimensi dalam kualitas pelayanan, yaitu bukti langsung (tangibles), kehandalan (reliability), daya tanggap (responsibility), jaminan (assurance) dan empati (empathy). Dengan menilai dimensi-dimensi tersebut maka akan diketahui secara jelas tingkat kepuasan masyarakat terhadap kualitas pelayanan yang dilakukan oleh lembaga kepolisian. Dengan dasar uraian di atas maka jelas terlihat adanya pengaruh yang signifikan antara kualitas pelayanan dengan kepuasan masyarakat, untuk itu model kerangka pemikiran dalam penelitian ini dapat digambarkan sebagai berikut : 


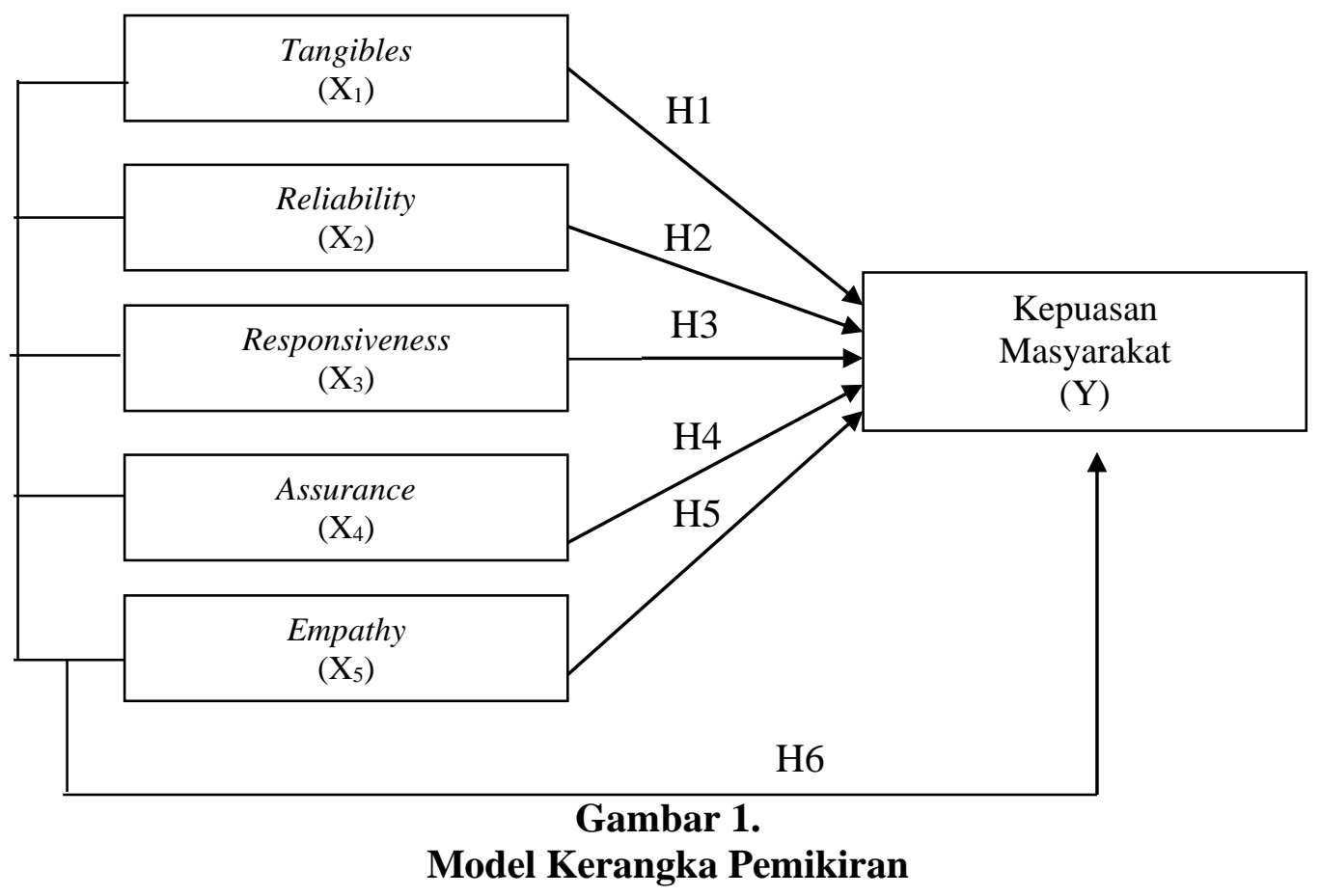

\section{Hipotesis}

Hipotesis penelitian adalah jawaban sementara terhadap pertanyaan penelitian dan harus diuji kebenarannya lewat pengumpulan data-data dan penganalisaan data penelitian (Azwar, 2003 : 49). Dalam penulisan ini hipotesis yang penulis ajukan adalah sebagai berikut:

H1: Terdapat pengaruh signifikan faktor bukti langsung (tangibles) terhadap kepuasan masyarakat pelapor pada Polsek Tengaran Polres Semarang.

H2: Terdapat pengaruh signifikan faktor kehandalan (reliability) terhadap kepuasan masyarakat pelapor pada Polsek Tengaran Polres Semarang.

H3: Terdapat pengaruh signifikan faktor daya tanggap (responsiveness) terhadap kepuasan masyarakat pelapor pada Polsek Tengaran Polres Semarang.

H4: Terdapat pengaruh signifikan faktor jaminan (assurance) terhadap kepuasan masyarakat pelapor pada Polsek Tengaran Polres Semarang.

H5: Terdapat pengaruh signifikan faktor empati (empathy) terhadap kepuasan masyarakat pelapor pada Polsek Tengaran Polres Semarang. 
H6: Terdapat pengaruh signifikan faktor tangibles, reliability, responsiveness, assurance dan empathy secara simultan terhadap kepuasan masyarakat pelapor pada Polsek Tengaran Polres Semarang.

\section{METODE PENELITIAN}

Dalam penelitian ini, jenis penelitian yang digunakan adalah jenis penelitian eksplanatori. Dalam penelitian ini seluruh populasi diambil seluruhnya menjadi sampel, jadi sampel dalam penelitian ini adalah sebanyak 65 orang. Hal tersebut dilakukan mengingat jumlah populasi yang kurang dari 100, maka seluruh populasi dijadikan sampel (Arikunto, 2003 : 115). Untuk itu teknik yang digunakan dalam penentuan jumlah sampel penelitian ini adalah sampling jenuh/sensus, yaitu cara pengambilan sampel dengan mengambil semua anggota populasi menjadi sampel (Hidayat, 2010:83).

Tabel 1

Definisi Operasional Variabel Penelitian

\begin{tabular}{|c|c|c|}
\hline No & Variabel & Definisi Operasional \\
\hline 1 & $\begin{array}{l}\text { Bukti Langsung } \\
\text { (tangibles) }\end{array}$ & $\begin{array}{l}\text { a) Kondisi bangunan memenuhi standar kenyamanan dan } \\
\text { keamanan. } \\
\text { b) Dukungan peralatan moderen dalam menunjang pelayanan. } \\
\text { c) Penampilan petugas yang menarik, rapi dan bersih. } \\
\text { d) Sarana komunikasi petugas layak dan memadai. }\end{array}$ \\
\hline 2 & $\begin{array}{l}\text { Kehandalan } \\
\text { (reliability) }\end{array}$ & $\begin{array}{l}\text { a) Kemampuan petugas sesuai dengan waktu yang dijanjikan. } \\
\text { b) Keseriusan petugas dalam menangani keluhan pelanggan. } \\
\text { c) Petugas menerapkan prosedur yang benar dalam menangani } \\
\text { keluhan pelanggan. } \\
\text { d) Keakuratan petugas dalam menangani setiap keluhan } \\
\text { pelanggan. }\end{array}$ \\
\hline 3 & $\begin{array}{l}\text { Daya tanggap } \\
\text { (responsiveness) }\end{array}$ & $\begin{array}{l}\text { a) Kemudahan presedur pelayanan yang ditetapkan. } \\
\text { b) Kecepatan petugas dalam memberikan pelayanan. } \\
\text { c) Kesediaan petugas dengan segera menangani keluhan } \\
\text { pelanggan. } \\
\text { d) Ketepatan petugas dalam menangani keluhan pelanggan. }\end{array}$ \\
\hline 4 & $\begin{array}{l}\text { Jaminan } \\
\text { (assurance) }\end{array}$ & $\begin{array}{l}\text { a) Sikap sopan petugas dalam memberikan pelayanan kepada } \\
\text { pelanggan. } \\
\text { b) Keramahan petugas dalam melayani pelanggan. } \\
\text { c) Kemampuan petugas dalam menangani keluhan pelanggan. } \\
\text { d) Tanggung jawab petugas dalam menangani keluhan } \\
\text { pelanggan. }\end{array}$ \\
\hline 5 & Empati (empathy) & $\begin{array}{l}\text { a) Kemampuan petugas memberikan perlindungan } \\
\text { pelanggan. } \\
\text { b) Kemampuan petugas melakukan pendekatan kepada }\end{array}$ \\
\hline
\end{tabular}




\begin{tabular}{|c|l|l|}
\hline & \multicolumn{2}{|c|}{ pelanggan. } \\
& & $\begin{array}{l}\text { c) Kemampuan petugas dalam memberikan kenyamanan } \\
\text { pada pelanggan. } \\
\text { d) Kemampuan petugas dalam mengetahui kemauan } \\
\text { pelanggan. }\end{array}$ \\
\hline 6 & Kepuasan & $\begin{array}{l}\text { a) Reputasi perusahaan semakin positif di mata konsumen } \\
\text { pada umumnya dan pelanggan pada khususnya. }\end{array}$ \\
& $\begin{array}{l}\text { b) Dapat mendorong terciptanya loyalitas pelanggan. } \\
\text { c) Memungkinkan terciptanya rekomendasi dari mulut ke } \\
\text { mulut (word of mouth) yang menguntungkan bagi } \\
\text { perusahaan sehinggga semakin banyak orang yang akan } \\
\text { membeli dan menggunakan produk/ jasa perusahaan. } \\
\text { d) Hubungan antara perusahaan dan para pelanggan menjadi } \\
\text { harmonis. }\end{array}$ \\
\hline
\end{tabular}

\section{Teknik Analisis Data}

Teknik analisis data yang digunakan adalah analisis regresi linera berganda, setelah sebelumnya dilakukan pengujian validitas dan reliabilitas. Selanjutnya untuk pengujian hipotesis menggunakan uji $\mathrm{t}$ dan uji $\mathrm{F}$. Koefisien Determinasi digunakan untuk mengetahui besarnya sumbangan independen ( $\mathrm{Xi}=$ tangibles $(\mathrm{X} 1)$, reliability $(\mathrm{X} 2)$, responsiveness (X3), assurance (X4) dan empathy $(\mathrm{X} 5))$ terhadap variabel dependen ( $\mathrm{Y}=$ Kepuasan Masyarakat Pelapor).

\section{ANALISIS DATA DAN PEMBAHASAN}

\section{Analisis Data}

Uji Validitas digunakan untuk mengukur instrumen penelitian yaitu kuesioner sebelum instrumen tersebut dioperasionalisasikan. Maksudnya bahwa setiap pertanyaan atau pernyataan terkait dengan masing-masing indikator dari tiap variabel perlu diuji untuk diketahui tingkat validitas atau keabsahannya. Hasil uji validitas menunjukkan bahwa nilai r-hitung masing-masing instrumen $(0,742-0,947)>$ r-tabel $(0,244)$, maka seluruh butir pernyataan valid. Berkaitan dengan hal tersebut, maka kuesioner penelitian dapat digunakan sebagai sarana mengukur, dan mengungkap data variabel penelitian secara tepat. Adapun hasil uji reliabilitas dapat dilihat pada table di bawah ini: 
Tabel 2

Hasil Uji Reliabiltas

\begin{tabular}{|ll|c|c|c|}
\hline \multicolumn{1}{|c|}{ Variabel } & Alpha & Pembanding & Keterangan \\
\hline 1. & Tangibles $(X 1)$ & 0,8858 & 0,6 & Reliabel \\
\hline 2. & Reliability $(X 2)$ & 0,8380 & 0,6 & Reliabel \\
\hline 3. & Responsiveness $(X 3)$ & 0,8652 & 0,6 & Reliabel \\
\hline 4. & Assurance $(X 4)$ & 0,8531 & 0,6 & Reliabel \\
\hline 5. & Empathy $(X 5)$ & 0,8472 & 0,6 & Reliabel \\
\hline 6. & Kepuasan Masyarakat $(\mathrm{Y})$ & 0,8247 & 0,6 & Reliabel \\
\hline
\end{tabular}

Berdasarkan data pada tabel di atas dapat dilihat bahwa besar nilai cronbach alpha variabel berkisar antara 0,8247 s/d 0,8858 >0,6, sehingga kuesioner dinyatakan reliabel. Sehingga instrumen yang digunakan dalam kuesioner penelitian ini dapat dipercaya untuk digunakan sebagai alat pengumpul data.

\section{Analisis Regresi Linier Berganda}

Dari hasil analisis data penelitian dengan menggunakan alat analisis regresi liner berganda diperoleh data sebagai berikut :

Tabel 3

Analisis Regresi Berganda

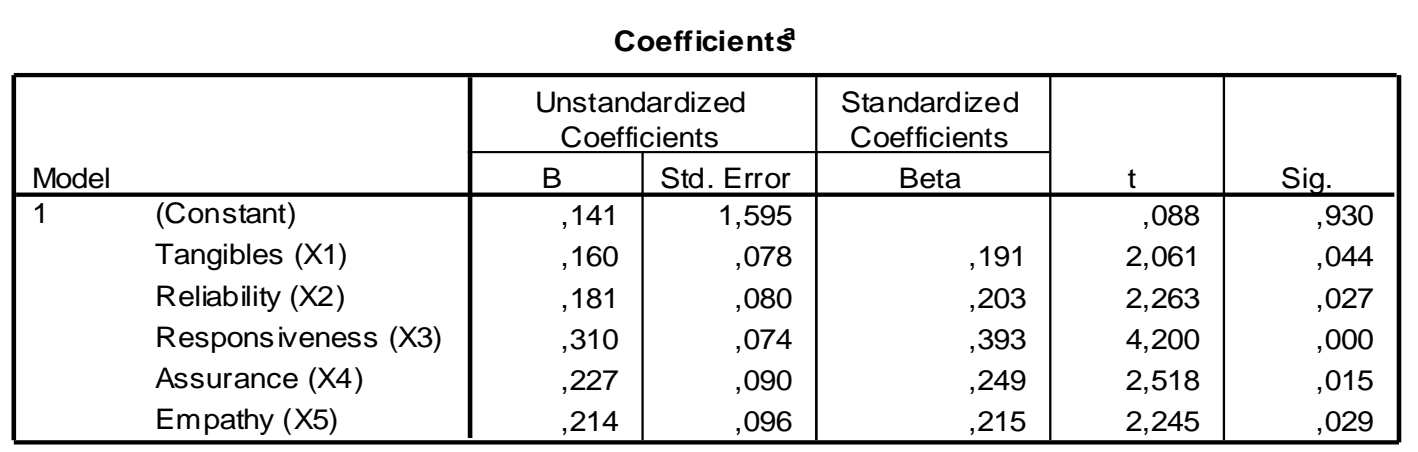

a. Dependent Variable: Kepuasan Masyarakat (Y)

Berdasarkan hasil analisis data pada tabel di atas dapat diuraiakan persamaan sebagai berikut: $Y=0,141+0,160 X_{1}+0,181 X_{2}+0,310 X_{3}+0,227 X_{4}+0,214 X_{5}$

Dari persamaan di atas dapat diuraian penjelasan sebagai berikut :

1. Nilai 0,141 adalah konstanta (a), besar nilai konstanta tersebut dapat diartikan tanpa ada variabel tangible $(X 1)$, reliability $(X 2)$, responsibility $(X 3)$, assurance $(X 4)$, dan 
empathy (X5), maka besarnya nilai kepuasan masyarakat pelapor (Y) adalah 0,141 satuan.

2. Nilai 0,160 adalah nilai koefisien regresi variabel tangibles $\left(\mathrm{b}_{1}\right)$, nilai tersebut dapat diartikan apabila dilakukan peningkatan kualitas pelayanan pada dimensi tangibles $\left(\mathrm{X}_{1}\right)$ sebesar satu-satuan, akan meningkatkan kepuasan masyarakat pelapor pada Polsek Tengaran Polres Semarang sebesar 0,160 satuan dengan asumsi variabel lainnya dianggap tetap atau ceteris paribus.

3. Nilai 0,181 , merupakan koefisien regresi variabel reliability $\left(\mathrm{b}_{2}\right)$, nilai tersebut dapat diartikan apabila dilakukan peningkatan kualitas pelayanan pada dimensi reliability $\left(\mathrm{X}_{2}\right)$ sebesar satu-satuan, akan meningkatkan kepuasan masyarakat pelapor pada Polsek Tengaran Polres Semarang sebesar 0,181 satuan dengan asumsi variabel lainnya dianggap tetap atau ceteris paribus.

4. Nilai 0,310, merupakan koefisien regresi variabel responsiveness $\left(b_{3}\right)$, nilai tersebut dapat diartikan apabila dilakukan peningkatan kualitas pelayanan pada dimensi responsiveness $\left(\mathrm{X}_{3}\right)$ sebesar satu-satuan, akan meningkatkan kepuasan masyarakat pelapor pada Polsek Tengaran Polres Semarang sebesar 0,310 satuan dengan asumsi variabel lainnya dianggap tetap atau ceteris paribus.

5. Nilai 0,227, merupakan koefisien regresi variabel assurance ( $\left.\mathrm{b}_{4}\right)$, nilai tersebut dapat diartikan apabila dilakukan peningkatan kualitas pelayanan pada dimensi assurance $\left(\mathrm{X}_{4}\right)$ sebesar satu-satuan, akan meningkatkan kepuasan masyarakat pelapor pada Polsek Tengaran Polres Semarang sebesar 0,227 satuan dengan asumsi variabel lainnya dianggap tetap atau ceteris paribus.

6. Nilai 0,214 , merupakan koefisien regresi variabel empathy $\left(\mathrm{b}_{5}\right)$, nilai tersebut dapat diartikan apabila dilakukan peningkatan kualitas pelayanan pada dimensi empathy $\left(\mathrm{X}_{5}\right)$ sebesar satu-satuan, akan meningkatkan kepuasan masyarakat pelapor pada Polsek Tengaran Polres Semarang sebesar 0,214 satuan dengan asumsi variabel lainnya dianggap tetap atau ceteris paribus. 


\section{Pengujian Hipotesis Penelitian}

Pengujian hipotesis I dilakukan dengan uji t. Pengujian ini bertujuan untuk mengetahui pengaruh faktor bukti langsung (tangibles) terhadap kepuasan masyarakat pelapor pada Polsek Tengaran Polres Semarang. Hasil uji t diperoleh nilai t-hitung sebesar 2,061, sementara nilai t-tabel pada tingkat signifikansi 5\%/2 $(0,025)$ dan derajad bebas $59(\mathrm{n}-\mathrm{k}-1=65-5-1)$ adalah sebesar 2,001. Sehingga nilai thitung $(2,061)>$ t-tabel $(2,001)$, berarti bukti langsung (tangibles) secara parsial mempunyai pengaruh signifikan terhadap kepuasan masyarakat pelapor pada Polsek Tengaran Polres Semarang. Pengujiuan pengaruh faktor kehandalan (reliability) terhadap kepuasan masyarakat pelapor pada Polsek Tengaran Polres Semarang diperoleh nilai t-hitung $=2,263$, dan t-tabel $=2,001(\alpha=5 \% / 2 \mathrm{dan} \mathrm{df}=59)$, berarti thitung $(2,263)>t$-tabel $(2,001)$. Dengan demikian kesimpulannya, terdapat pengaruh signifikan faktor kehandalan (reliability) terhadap kepuasan masyarakat pelapor pada Polsek Tengaran Polres Semarang.

Pengujian pengaruh faktor daya tanggap (responsiveness) terhadap kepuasan masyarakat pelapor pada Polsek Tengaran Polres Semarang diperoleh nilai t-hitung $=$ 4,200 dan t-tabel $=2,001(\alpha=5 \% / 2$ dan $\mathrm{df}=59)$, berarti t-hitung $(4,200)>\mathrm{t}$-tabel $(2,001)$. Dengan demikian kesimpulannya, terdapat pengaruh signifikan faktor daya tanggap (responsiveness) terhadap kepuasan masyarakat pelapor pada Polsek Tengaran Polres Semarang. Pengujian pengaruh faktor jaminan (assurance) terhadap kepuasan masyarakat pelapor pada Polsek Tengaran Polres Semarang diperoleh nilai t-hitung $=2,518$ dan t-tabel $=2,001(\alpha=5 \% / 2$ dan $\mathrm{df}=59)$, berarti t-hitung $(2,518)>$ t-tabel $(2,001)$. Dengan demikian terdapat pengaruh signifikan faktor jaminan (assurance) terhadap kepuasan masyarakat pelapor pada Polsek Tengaran Polres Semarang. Pengujian hipotesis V penelitian dilakukan untuk menguji pengaruh signifikan faktor empati (empathy) terhadap kepuasan masyarakat pelapor pada Polsek Tengaran Polres Semarang. Hasil uji t diperoleh nilai nilai t-hitung $=2,245$ dan t-tabel $=2,001(\alpha=5 \% / 2 \mathrm{dan} \mathrm{df}=59)$, berarti t-hitung $(2,245)>\mathrm{t}$-tabel $(2,001)$. Dengan demikian kesimpulannya terdapat pengaruh signifikan faktor empati (empathy) terhadap kepuasan masyarakat pelapor pada Polsek Tengaran Polres 
Semarang. Pengujian hipotesis VI dilakukan dengan uji $\mathrm{F}$ untuk melihat apakah variabel independen (tangibles, reliability, responsiveness, assurance dan empathy) secara simultan mempunyai pengaruh signifikan terhadap variabel dependen (kepuasan masyarakat pelapor). Dengan menggunakan signifikansi 5\% $(\alpha=0,05)$ dan degree of freedom $(\mathrm{n}-\mathrm{k}-1)=59$ dan $(\mathrm{k})=5$, diperoleh nilai F-tabel sebesar 2,37, sementara nilai F-hitung-nya adalah sebesar Nilai $F_{\text {hitung }}$ dari perhitungan dengan program komputer statistik sebesar 16,152, lebih jelasnya lihat tabel Anova di bawah ini :

\section{Tabel 4}

Uji F

ANOVA

\begin{tabular}{|ll|r|r|r|r|r|}
\hline \multicolumn{1}{|c|}{} & \multicolumn{1}{c|}{$\begin{array}{c}\text { Sum of } \\
\text { Model }\end{array}$} & Squares & df & Mean Square & F & Sig. \\
\hline 1 & Regression & 81,467 & 5 & 16,293 & 16,152 &, $000^{\mathrm{a}}$ \\
& Residual & 59,517 & 59 & 1,009 & & \\
& Total & 140,985 & 64 & & & \\
\hline
\end{tabular}

a. Predictors: (Constant), Empathy (X5), Reliability (X2), Responsiveness (X3), Tangibles (X1), Assurance (X4)

b. Dependent Variable: Kepuas an Masyarakat (Y)

Membandingkan kedua nilai $\mathrm{F}$ tersebut dapat dikemukakan bahwa nilai F-hitung $(16,152)>$ F-tabel $(2,37)$, sehingga Ho ditolak dan Ha diterima, maka pernyataan hipotesis VI penelitian, “Terdapat pengaruh signifikan faktor tangibles, reliability, responsiveness, assurance dan empathy secara simultan terhadap kepuasan masyarakat pelapor pada Polsek Tengaran Polres Semarang”, diterima.

Bagian akhir dari analisis data adalah menghitung dan menganalis koefisien determinasi yang bertujuan untuk mengetahui besarnya kontribusi variabel independen yaitu tangibles (X1), reliability (X2), responsiveness (X3), assurance (X4), dan empathy (X5) terhadap variabel kepuasan masyarakat pelapor (Y). Adapun hasilnya dapat dilihat pada tabel di bawah ini : 


\section{Tabel 5}

\section{Koefisien Determinasi}

\section{Model Summary}

\begin{tabular}{|l|r|r|r|r|}
\hline Model & $\mathrm{R}$ & $\mathrm{R}$ Square & $\begin{array}{c}\text { Adjusted } \\
\text { R Square }\end{array}$ & $\begin{array}{c}\text { Std. Error of } \\
\text { the Estimate }\end{array}$ \\
\hline 1 &, $760^{\mathrm{a}}$ &, 578 &, 542 & 1,00437 \\
\hline
\end{tabular}

a. Predictors: (Constant), Empathy (X5), Reliability (X2), Responsiveness (X3), Tangibles (X1), Assurance (X4)

Tabel di atas menunjukkan bahwa nilai Adjusted $R$ Square adalah sebesar 0,542, berarti variabel independen yaitu tangibles $(X 1)$, reliability $(X 2)$, responsiveness (X3), assurance (X4), dan empathy (X5) mampu menjelaskan variabel dependen, yaitu kepuasan masyarakat pelapor (Y) sebesar 54,20\%, sedang sisanya 45,80\% dijelaskan oleh variabel lainnya yang tidak diteliti, misal: lokasi, dan reputasi Polsek Tengaran Polres Semarang.

\section{KESIMPULAN}

Hasil penelitian menunjukkan variabel responsiveness, variabel assurance. variabel empathy,variabel reliability dan variabel tangibles berpengaruh terhadap kepuasan pihak pelapor. Berkaitan dengan tersebut maka hal yang perlu dilakukan oleh pimpinan Polsek Tengaran adalah mengajukan anggaran kepada pihak Polri untuk meningkatkan kualitas bangunan yang digunakan, serta meningkatkan kualitas peralatan yang digunakan, misal: peralatan komputer, baik dari aspek kualitas maupun kuantitasnya, sebab hal tersebut akan mempercepat proses pelayanan yang dilakukan kepada masyarakat.

Hasil penelitian juga menunjukkan, bahwa nilai adjusted $R$ square hasil analisis data adalah sebesar 54,20\%, sedang sisanya 45,80\% dijelaskan oleh variabel lainnya yang tidak diteliti. Berkaitan dengan temuan tersebut maka penting bagi peneliti selanjutnya untuk mengikutsertakan variabel-variabel lain misal: lokasi, dan reputasi Polsek Tengaran Polres Semarang dalam menilai kepuasan masyarakat pelapor. 


\section{DAFTAR PUSTAKA}

Arikunto, Suharsimi, 2003. Prosedur Penelitian Suatu Pendekatan Praktek. PT. Rineka Cipta, Jakarta.

Azwar, Syaifuddin, 2003. Metode Penelitian. Pustaka Pelajar Offset, Yogyakarta.

Bloemer, J., dkk. 2002. "On The Relationship between Perceived Service Quality, Service Loyalty and Switching Costs" dalam International Journal of Industry Management, Vol. 9 No. 5, hlm. 436-53.

Ellitan, Lenna. 2001. Strategi Mendongkrak Kualitas Pelayanan. Jurnal Ekonomi kajian Ekonomi, Manajemen dan Akuntansi, Sekolah Tinggi Ilmu Ekonomi Indonesia. No. 15. Januari-Maret, hal. 14-24.

Ghozali, Imam, 2004. Analisis Multivariate Dengan Program SPSS. Badan Penerbit Universitas Diponegoro, Semarang.

Hidayat, A. Aziz Alimul. Metode Penelitian Kebidanan. Salemba Medika, Jakarta.

Hurriyati, Ratih, 2005. Bauran Pemasaran dan Loyalitas Konsumen. Alfabeta, Bandung.

Indrawati, A., 2011. Pengaruh Kualitas Layanan Lembaga Pendidikan terhadap Kepuasan Konsumen. Jurnal Ekonomi Bisnis, TH. 16, NO. 1 (MARET 2011), hal. 25-35.

Istiqomah, 2014. Analisis Kepuasan Publik Atas Kualitas Pelayanan di Sat Lantas Polres Sukoharjo. Seminar Nasional dan Call For Papers Uniba 2014, hal. 7996.

Khoirista, Yulianto dan Mawardi, 2015. Pengaruh Kualitas Pelayanan Terhadap Kepuasan Pelanggan (Survey Pada Pelanggan Fedex Express Surabaya). Jurnal Administrasi Bisnis (JAB), Vol. 25 No. 2 (Agustus 2015), hal. 1-7.

Kotler, Philip, 2000. Manajemen Pemasaran di Indonesia: Analisis, Perencanaan, implementasi, dan pengendalian. Salemba Empat, Jakarta.

Kotler, Philip, 2009. Manajemen Pemasaran. Erlangga, Jakarta.

Lovelock, C.H. dan Wright, L.K. 2007. Manajemen Pemasaran. PT. Indeks, Jakarta.

Lupiyoadi, Rambat, 2009. Manajemen Pemasaran Jasa. Salemba Empat, Jakarta.

Notoatmodjo, Soekidjo, 2002. Metodologi Penelitian Kesehatan. Rineka Cipta, Jakarta.

Riduwan, 2003. Skala Pengukuran Variabel-Variabel Penelitian. AlfaBeta, Bandung. 
Santosa, Purbayu Budi dan Ashari, 2003. Statistika Teori dan Aplikasi dengan Program MS. Exel \& SPSS Versi 11. Universitas Diponegoro, Semarang.

Sasmita, Jumiati, 2007. Analisis Produktivitas Kerja Pegawai Negeri Sipil (PNS) di Propinsi Riau. Universitas Negeri Riau (UNRI), Riau.

Setiyawati, Antari, 2009. Studi Kepuasan Pelanggan untuk Mencapai Loyalitas Pelanggan (Studi Kasus Pada Konsumen Toko Bangunan Bangun Rejeki Semarang). Tesis. Program Magister Manajemen, UNDIP, Semarang.

Stanton, J. William. 2005. Prinsip-prinsip Pemasaran. Erlangga, Jakarta.

Subroto, Ditanto Aris, 2010. Komunikasi Dan Motivasi Kerja Terhadap Kinerja Karyawan Pada Dinas Pendapatan, Pengelolaan Keuangan Dan Aset Daerah Kota Salatiga. Tesis. Program Pasca Sarjana (S2) Magister Manajemen Universitas Islam Sultan Agung, Semarang.

Sugiarto dan Supramono, 2003. Statistika. Andi Offset, Yogyakarta.

Sugiyono, 2002. Statistika Untuk Penelitian. CV. Alfabeta, Bandung.

Sukandarrumidi, 2006. Metode Penelitian : Petunjuk Praktis Untuk Peneliti Pemula. Gadjah Mada University Press, Yogyakarta.

Supranto, Johanes, 2001. Pengukuran Tingkat Kepuasan Pelanggan. Rineka Cipta, Jakarta.

Supriyati, 2004. Kepuasan Pasien Terhadap Mutu Pelayanan Keperawatan Di Ruang Rawat Inap I RS DR. Sardjito Yogyakarta. Skripsi. Program Ilmu Keperawatan Fakultas Kedokteran Universitas Gadjah Mada, Yogyakarta.

Tjiptono, Fandy, 2000. Strategi Pemasaran. Andi Offset, Yogyakarta.

---------------, 2004. Prinsip-Prinsip Total Quality Service. Andi Offset, Yogyakarta.

----------------, 2007. Pemasaran Jasa. Bayumedia Publising, Malang.

----------------, dan Anastasia Diana, 2001. Total Quality Management. Andi Ofset, Yogyakarta.

Wijaya, Juhana. 2005. Pelayanan Prima. Armico, Bandung. 